\title{
Revealing Social Accounting in Management Residual Business Result in Cooperatives
}

\author{
Lucy Sri Musmini ${ }^{1, *}$ Luh Indrayani ${ }^{1}$ I Gede Agus Pertama Yudantara ${ }^{1}$ \\ ${ }^{1}$ Department of Economics and Accounting, Universitas Pendidikan Ganesha, Singaraja, Indonesia \\ *Corresponding author.Email: sri.musmini@undiksha.ac.id
}

\begin{abstract}
This study aims to reveal social accounting in managing residual business results in cooperatives. This research was conducted by tracing and exploring the understanding of social accounting in the context of residual business results in cooperatives. This qualitative research uses a phenomenological approach. A phenomenological approach that aims to understand the response to the existence of humans/society and experiences that are understood in interacting. Data collection was done by interview, observation, documentation, and literature review. Research data analysis of data organization, reading data, horizontalization, determining noema and noesis, intention analysis, making narratives, and reporting participant experiences. The results showed (1) that the residual business result at the Swastiastu Credit Cooperative was allocated to several elements: reserve funds, depositor services, borrowing services, management funds, employee funds, social funds, and DPDK. Funds and education funds, (2) Social accounting the Swastiastu Credit Cooperative is shown by the existence of a social fund program and a funeral fund with the premise of helping each other among cooperative members and contributing to community activities around the cooperative.
\end{abstract}

Keywords: Social Accounting, Phenomenology, Residual Business Results, and Cooperatives.

\section{INTRODUCTION}

Social accounting is based on stakeholder theory, business is managed not only profit-oriented but also social and environmental. Organizations carrying out their operations are based on the 3P, namely: profit, people, and the planet, both business companies and nonprofit organizations [1]. So, the company's activities are profit-oriented, stock trading markets, and others that emphasize profitability, effectiveness, and efficiency. Furthermore, the presence of accounting is to discipline the public [2] in the sense of calculating how a business or organization earns income and being able to punish each individual for caring about social and environmental problems, even spiritual transcendence.

The company's operational sustainability is strongly influenced by its economic, social, and environmental performance. This means that the company must be financially secure, eliminate ecological impacts and pay attention to the social effects of its operational activities. Social aspects include the effect of the company on its employees and the social system of its community. The emphasis on the people principle refers to the company's concern for the community, which can be interpreted as concern for the human aspect of the company or organization.

Social accounting helps know the performance and public perception through qualitative and quantitative information obtained [3]. The basic argument is that organizations must provide social and environmental interactions to broader financial stakeholders. Accounting is closely associated with social dislocation and environmental degradation due to the further impact of capitalism. Social accounting can act as an agent of change by way of emancipation so that it affects the community's cultural awareness. Social accounting can illustrate that accounting can contribute to refreshing the public space behind its direct influence from an economic point of view [4].

According to Killian and Regan, social accounting can establish legitimacy in local communities and play an important role in community processes [5]. Furthermore, Killian and Regan argued that the social accounting process is a narrative that contains symbolic power that leads to legitimacy and authority for the company. The symbolic power of social accounting also leads to the restructuring of social relations, self-identity, and accountability. The contribution of social accounting to 
corporate legitimacy is not a broad economic spread that can perpetuate legitimacy but instead emphasizes the participation of community groups [5].

Social accounting is the process of communicating the social and environmental impacts of an organization's economic actions to benefit specific groups in society and society at large. The scope of social accounting includes several aspects [3], as shown in Figure 1.

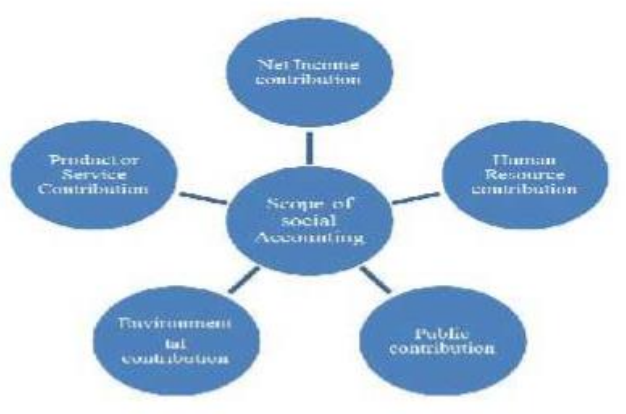

Figure 1. Scope of social accounting

An explanation of each aspect is described below. (1) Net Profit Contribution: The primary objective of a business is to earn profit. The growing attention to corporate social activities will not diminish the importance of profit for the company. On the contrary, it adds to the significance of the company's net income by drawing attention to the circumstances in which it has been produced. Companies must ensure that profits are earned within a legal framework where "profits in a socially acceptable manner," (2) Human Resources Contribution: This reflects the organization's influence on the organization's human resources. Organizational activities include recruitment policies and practices, training, experience building, job enrichment, wages and salaries, harmony of employees and organizational goals, occupational safety and health, (3) Contribution to Society: This reflects the impact of corporate activities on individuals generally in outside the organization. The organization's activities include donations, community volunteering, training, and employing people with disabilities, (4) Contribution to the Environment: This reflects the impact of the company's activities on the environment - clean industrial activities by not using irreplaceable resources and clean production of sod waste. Corporate social goals can be found in reducing the adverse external social effects of the industrial output and adopting more efficient technologies to minimize the use of irreplaceable resources and production waste, (5) Contribution of Products or Services: This area deals with the qualitative aspects of the organization's products or services. This includes product usability, product durability, product and service safety, and the welfare role of the product or service. This also includes customer satisfaction, honesty in advertising their products, and others.

Cooperatives are one form of economic organization in Indonesia. Cooperative operational activities reported in the financial statements produce residual business results. In cooperatives, there are no employers and workers who have conflicting interests (see agency theory). Work is done together, and responsibilities are carried out together for the survival of the cooperative. The primary purpose of cooperatives is to organize activities to meet the needs of living together and, as well as possible, not to pursue profits. Although cooperatives seek profit, profit is not the goal; the main goal is to maintain common interests and provide for the necessities of life together. In contrast to the company, its members who invest in the company do not participate much in the business, more waiting for the distribution of profits at the end of the year, while the members of the cooperative all participate in the effort and are responsible.

By-Law Number 25 of 1992 concerning Cooperatives, Cooperatives are identified as business entities consisting of one person or cooperative legal entity by basing their activities on cooperative principles and a people's economic movement based on the principle of kinship [6]. The identity of cooperatives clearly shows that cooperatives are established and carry out their activities based on honesty, openness, social responsibility, and care for others to realize an economic, democratic life with democratic, familial, and open characteristics [7]. The life of the cooperative is based on several principles, namely: (1) membership is voluntary and open, (2) management is carried out democratically, (3) the distribution of the residual business results is carried out somewhat in proportion to the number of business services of each member, (4) the provision of services is limited to the capital. , (5) independence, (6) cooperative education, and (7) cooperation between cooperatives [6].

Cooperatives have their uniqueness compared to other organizations because cooperatives carry out their activities based on kinship as a people's economic movement. Cooperatives also need to pay attention to professional management [8]. When cooperatives are grouped as profit-oriented organizations, it is also not true because cooperatives prioritize the spirit of togetherness with the principle of kinship. According to Bung Hatta, the management of cooperatives is different from the private sector, meaning that cooperatives are not individual organizations seeking profit alone, but rather a collective organization to meet the necessities of life [9]. A similar opinion was expressed by [10] that cooperatives as jointly owned businesses have the primary goal of seeking benefits for their members, not for profit. Cooperatives are owned by all their members so that cooperatives are not relevant to seek gain from their members. On the other hand, cooperatives are grouped as social organizations; cooperatives also pursue growth according to their characteristics.

The characteristics and spirit of Indonesian cooperatives are very different from what is conditioned on the current assessment of cooperative performance. The part of cooperatives is the identity of cooperative 
members who have three functions: owners, users, and controllers of cooperatives, with the concept of, by, and for members. Cooperatives are a forum for voluntary cooperation to help themselves with honesty, openness, social responsibility, and care, carried out democratically [11]. Cooperatives exist to advance the welfare of their members through kinship and cooperation. Cooperatives are self-governing associations that serve as a forum for people to cooperate voluntarily (members). The purpose of becoming a volunteer member is to assist oneself. Cooperatives have organizational and business aspects; cooperatives as business entities are democratically owned and controlled by their members [11].

The second component of collective identity is a set of fundamental values and ethical standards. Cooperatives are fundamentally about self-help, selfresponsibility, democracy, equality, individuality, and solidarity. Cooperatives' moral values include honesty, transparency, social responsibility, and concern for others. The third component of collective identity is the cooperative principles, which include voluntary and open membership, democratic oversight by members, economic participation by members, autonomy and independence, education, training, and information, cooperative cooperation, and community concern [11]. Cooperative characteristics become the soul of a member-owned cooperative organization. The cooperative's goal of enhancing members' welfare through kinship is attainable.

According [12], however, money is also an important consideration in cooperatives, which place a premium on treating each person or member equally and ensuring full participation in the decision-making process. One person, one vote is adhered to (not one share, one vote). In order to achieve the primary goal of maximizing the benefits for members, cooperatives are founded on the principles of individual awareness and solidarity [12]. The cooperative's goal of prioritizing benefits for its members is in line with Bung Hatta's thinking. Bung Hatta's review is based on the basic assumption of awareness of the nation's ideals, namely a prosperous and prosperous society [13]. People's prosperity and well-being can be achieved through economic democracy, in which members of the cooperative have supreme sovereignty over the organization.

Cooperatives should be oriented towards economic goals and social goals by the identity of the cooperative. Socially-oriented organizations such as co-ops give back some of their profits to its members, who in turn benefit from it. Members of a cooperative should be aware of the amount of the collective's residual business profit, as it is the result of a cooperative's members' joint efforts. Thus, cooperative members can obtain benefits that ultimately increase their welfare.

Management of residual business results is important to put forward the idealism of cooperatives in the aspect of togetherness. The realization of togetherness in managing residual business results can improve the implementation of cooperative ideals in communal life from the social part. Social elements in managing residual business results in social accounting need to be disclosed to enhance understanding of social accounting in collaborative organizational practices.

Based on the background of the research described earlier, the focus of this research is to reveal social accounting in managing residual business results. The research question that arises from the focus of this research is how social accounting is in managing residual business results in cooperatives. This research aims to uncover and understand social accounting in working residual business results in cooperatives. This research was conducted by tracing and exploring the understanding of social accounting in the context of residual business results in cooperatives.

This research is expected to provide benefits for the following parties: (1) theoretical contribution. The results of this study are expected to contribute ideas in management accounting on social accounting. This research is expected to reveal social accounting residual business results in cooperative accounting science, which prioritizes the human aspect. The results of this study can enrich the field of accounting, especially stakeholder theory, which is currently still less of a concern. (2) contributions to the government, especially those dealing with cooperatives, are expected to be input for making policies and regulations regarding cooperatives that further develop the human aspect of cooperative ideals of cooperatives. The study results can provide a regulatory basis for making rules for managing the residual business results of cooperatives. (3) practical contribution, the results of this study are expected to provide a management perspective on residual business results by the spirit of cooperatives for cooperative actors and practitioners.

This article discusses social accounting in cooperatives, especially regarding managing the residual results of their business. The second part of this paper describes the issue of social accounting and cooperatives. The third part describes the phenomenological research method to find answers to the problems in this article. The fourth and fifth sections describe the residual business results in cooperatives and social accounting for managing the residual business results of cooperatives. The last part of the article includes a provisional conclusion from the research results obtained on social accounting in cooperatives.

\section{METHOD}

This study uses a qualitative approach, research that does not use statistical calculations to achieve research objectives. The qualitative approach aims to gain a general understanding of social reality from the participant's perspective. This understanding is not 
determined beforehand but is obtained after analyzing the social reality that is the focus of the research. Based on this analysis, conclusions are then drawn in the form of an abstract general understanding of people's social life [14].

This study uses an interpretive paradigm, which views reality as something subjective, discovered, and interpreted. The interpretive paradigm emphasizes that research is carried out to understand the world's reality as it is. An understanding of the fundamental nature of the social world at the level of subjective experience. An account that emphasizes the existence of social order, solidarity, and actuality [8]. This paradigm aims to interpret and understand social phenomena [14]. Interpretive methodology, as a research procedure, produces descriptive data in the form of written words or words and the observable behavior of people.

Based on the research objective to uncover and understand reality, this research uses a phenomenological approach. A phenomenological approach that aims to understand the response to the existence of humans/society and experiences that are understood in interacting. This is in line with the expression of Creswell [15] that this phenomenological approach gives more attention to the description of the object of a concept or a phenomenon. Burrell and Morgan's [16] phenomenology consider understanding the meaning of daily human life (life-world) to uncover social problems and interpret how people act in everyday life.

This research was conducted to evaluate the performance of cooperatives on the micro dimension, namely as a cooperative organization. This research was conducted at the Swastiastu Credit Cooperative, whose head office is at Jalan Laksamana Barat No. 9 Singaraja, Bali, with operational scope in Buleleng Regency. The Swastiastu Credit Cooperative was founded on September 1, 1981, by 20 teachers and employees of the Swastiastu Foundation. The reason for choosing the research subject of the Swastiastu Credit Cooperative has been running for quite a long time with reasonably rapid development, namely since its establishment until now, seen from the growth in the number of cooperative members and the development of its joint activities. In addition, the Swastiastu Credit Cooperative is very active in suitable institutional activities, so that researchers hope to see a clearer picture of the current research theme.

This study refers to the data collection technique described by Sukoharsono and Putra [17]: (1) Observation: Observation collects data through direct observation or review. It is carefully and directly in the field or research location. In this case, the researcher guided the research design needed to visit the study site to now observe the various terms or conditions on the ground, (2) In-depth interview: In-depth interview is a data collection technique based on an intensive conversation with a specific purpose. Interviews were conducted to obtain information regarding the various issues raised in the study. This is done to get primary data as material for future analysis, (3) Documentation: Documentation is seeking data about things that are needed in the study, such as books, newspapers, magazines, and so on. Documentation is used to supplement the data obtained from interviewers and observation, (4) References Review: This study also takes the literature related to the problem in this study. Therefore, the references review is also necessary to determine the forms of social accountability accounting activity. After that, the data is analyzed by the following step: organize data, read all data, classifying the meaning of the informant's statement, describe the whole phenomenon, explain narratively and get meaning.

\section{RESULTS \& DISCUSSION}

\subsection{Residual Business Result Management In Cooperatives}

Cooperative is a business organization based on the principles of togetherness and kinship. Socio-economic aspects of cooperatives are inherent in their operational activities. In practice, cooperative operations look for profit because it is a business activity, but cooperatives, in taking their policies, also adhere to improving welfare based on togetherness and kinship.

In accounting reporting made as a form of accountability for operational accounting activities, the difference between income and cooperative operating costs, usually referred to as profit in private companies, is called residual business results. In cooperatives, residual business results resulting from the cooperative's operational performance will be returned partially to members. Each cooperative's residual business results management policy is different based on the joint member's decision, which can be changed through the annual member meeting.

The Swastiastu Credit Cooperative was founded on September 1, 1981, with 20 teachers and employees of the Swastiastu Foundation. The operational activities of the Swastiastu Credit Cooperative refer to the management of the Credit Union (CU). Credit unions can be described as non-profit institutions engaged in finance similar to banks that provide financial services according to the needs of their members. The management and supervision of credit unions are also carried out voluntarily by its members.

The Swastiastu Credit Cooperative, to date, has experienced rapid development from the membership that is limited to teachers and employees of the Swastiastu Foundation to be open to the general public since 1995. Until the end of 2020, the number of registered members was 9,354 people, which at the beginning consisted of only 34 people. Member. The capital accumulation of the Swastiastu Credit Cooperative is carried out by payment of principal savings, mandatory savings, and voluntary savings by its members. Initially, the Swastiastu Credit Cooperative set 
a central savings of IDR 5,000, mandatory IDR 500 per month, and voluntary savings of IDR 1,000 per month. Developments in 40 years of operation, the wealth of the Swastiastu Credit Cooperative until the end of 2020 has reached 90,990,782,712 rupiahs.

The management of residual business results at the Swastiastu Credit Cooperative by predetermined policies is allocated to several parts, as can be seen in table 1. the following. Let's look at the residual business results allocation of the Swastiastu Credit Cooperative in 2020. It can be seen that depository services have a much higher percentage than the allocation of residual business results to other parts, which is $52 \%$. The reason behind this figure was explained by Mr. Sandi as an advisor to the Swastiastu Credit Cooperative, according to the following interview excerpt

The fairness of the distribution of residual business results between $2 \%$ borrowers, $52 \%$ savers can be explained as follows. The difference is very far; the reason is that our principles are petrified; if you want to help, you must have capital. Then the more valued money. We hope that the capital will be more significant, so we don't have to borrow from other places. This is done to foster own prosperity and appreciation for depositors to be even more enthusiastic about saving in cooperatives. We are using a coupon system that is only given to Sibuhar.

The statement revealed that the Swastiastu Credit Cooperative encouraged its members to save more than borrowers.

Even the award for depositors over $50 \%$ of the residual business results obtained by the Swastiastu
Credit Cooperative is an outstanding award for cooperative members. The appreciation given by the joint to the depositor in the form of an allocation of residual business results distribution, which is much larger than the member who borrows, shows that the suitable educates its members to prioritize saving behavior over borrowing behavior. The encouragement to members towards saving attitudes with the appreciation is expected to have implications for the orientation of cooperative members to prefer saving rather than borrowing.

The Swastiastu Credit Cooperative's policy regarding managing residual business results shows that the cooperative wants to educate its members towards better behavior. If it is related to someone who tends to borrow, it means that they live life under the control of the other party. In addition, when someone makes a loan that unwittingly exceeds his ability to repay, it will cause mental stress in living life, even though in economics, the loan is still considered safe up to $60 \%$ of our wealth.

Prioritizing saving over-borrowing cannot be separated from Bung Hatta's view as an observer and cooperative activist and has even been confirmed as the Father of Cooperatives in Indonesia. He recommends cooperatives to be more active in raising unified capital from the savings of their members. The savings collected by cooperative members can show the strength of the joint in its independent management. The independence of collective leadership can be used to fight against the arrangement of other parties outside the cooperative, both from the collaborative management policymaking and the power of other parties, which prioritize the other party. If another party has controlled it, what about the roles and interests of the cooperative members. Who will support and fight for? Thus the suitable adheres to the principle of, by, and for members, which shows the

Table 1. List of Residual Business Results Allocations for Swastiastu Credit Cooperatives in 2020

\begin{tabular}{|c|l|r|r|}
\hline No. & \multicolumn{1}{|c|}{ Residual Business Results Allocation } & Percentage & \multicolumn{1}{|c|}{ Allocation value in 2020} \\
\hline 1 & Reserve fund & $30 \%$ & $358,126,058.10$ \\
\hline 2 & Depositor Service & $52 \%$ & $620,751,834.04$ \\
\hline 3 & Borrower Services & $2 \%$ & $23,875,070.54$ \\
\hline 4 & Management Fund & $7 \%$ & $83,562,746.89$ \\
\hline 5 & Employee Fund & $5 \%$ & $59,687,676.35$ \\
\hline 6 & Social Fund & $3.5 \%$ & $41,781,373.45$ \\
\hline 7 & DPDK & $0.2 \%$ & $2,387,507.05$ \\
\hline 8 & Education Fund & $0.3 \%$ & $3,581,260.58$ \\
\hline & & & $1,193,753,527.00$ \\
\hline
\end{tabular}

Source: 2020 Management Accountability Report

cooperative's desire to be truly independent and has its strength in supporting its operations.

Loan management of the Swastiastu Credit Cooperative also adheres to prioritizing using its capital in its operations for independence and convenience. The following statement by Mr. Sandi shows this opinion.

"According to puskopdit, if sugar is greater than the mandatory savings, it is good; we get great trust from 
members. However, it is different from the cooperative service, which checks if the capital itself is significant it will be healthier. If we have a lot of money, it will be easier to lend. If you use debt, it has risks; what if it is suddenly withdrawn? How do we return it, so confused? It's better to borrow a little, but it's safe because we use our capital. This can be safe because all employees can immediately cut their salaries."

The Puskopdit is the Arta Guna Credit Cooperative Center, which is the Swastiastu Credit Cooperative to join and take shelter by cooperative principles.

Based on the above opinion, it can be said that however cooperative operations must also consider the security factor, not only the growth factor. Cooperatives ' development will certainly be faster if they can channel more credit because cooperatives earn income from credit interest. However, when operations are more supported or sourced from outside party funds, it will cause anxiety for the cooperative if, at any time, it cannot pay its obligations to these outside parties. Cooperatives feel more comfortable when they can run their operations when they are not under pressure from outside parties who provide cooperative loans.

\subsection{Social Accounting Residual Business Result Management In Cooperatives}

Social accounting, also referred to as stakeholder accounting, has been a discussion since 1950 and has grown to the attention of researchers on social and environmental accounting since 25 years ago [18]. Social accounting is a method of how companies place value on the impact of their company's operations on society [3].

According to [3], the objectives of social accounting can be identified as follows: (1) to identify and measure the net social contribution of each company internally, as well as those arising from external factors that affect various layers of society, (2) to determine whether the strategies and individual company practices consistent with broad social accounting principles, (3) to provide relevant information regarding the objectives, programs, performance of the optimal use and contribution of company resources.

Social accounting can provide benefits to help people understand the social value that companies offer to society and their impact on stakeholders and social welfare. Blessings, on the other hand, social accounting can provide feedback on social has implications for companies to be more optimal to increase the company's legitimacy in the communities in which they operate [18]. In summary, social accounting in the context of this research can be interpreted as information related to cooperative operational activities with social benefits for cooperative members and the community as suitable stakeholders by placing values that are used as guidelines in joint activities.
The social aspect of the Swastiastu Credit Cooperative has been designed and outlined in its work program from the start in the form of social funds and funeral funds. Here is Mr. Sandi's statement about the social aspects of the Swastiastu Credit Cooperative when interviewed:

Social funds include donations for villages, for example, funds for sekaa Fortuna-teruni, education funds for children looking for new schools such as kindergarten-elementary schools, students with academic and non-academic achievements, funds for hospitalization for children, members who are hospitalized for at least three days and above.

The social aspect of the Swastiastu Credit Cooperative has also been reported in its financial statements when the cooperative management is held accountable every year. The social funds in the Swastiastu Credit Cooperative are education fund assistance, hospitalization compensation funds, student achievement assistance funds, and community organization assistance funds. Based on data obtained from the accountability report of the 2020 Swastiastu Credit Cooperative management, the following is the realization of the Social Fund as of December 31, 2021. Another social aspect of the policy of the Swastiastu Credit Cooperative is a funeral fund consisting of a bereavement compensation fund and a daperma. The bereavement compensation fund aims to ease the financial burden of the deceased member by providing compensation of Rp. 9,000,000, - while the husband or wife or child of the deceased member is given compensation of Rp. 4,000,000. Daperma is a loan risk fund to cover the loss of the cooperative because the deceased member still has credit dependents in the cooperative. Daperma was prepared by the cooperative to pay off the remaining loan of the deceased member up to Rp 100,000,000.

The following is the realization of the Swastiastu Credit Cooperative funeral fund in 2020 (Table 2 and Table 3).

Mr. Sandi also clarified this mourning fund program according to his statement below:

"Then there is mourning compensation, actually specifically funds from members but managed by cooperatives. Special mourning fund for death. Every time a member dies, they pay Rp. 2,000,-. Funds come specifically from cooperatives managed by cooperatives, not only for those who died but also for those grieving. The Sibuhar savings of 2000 per member will be used for mourning funds for every person who dies. Those who are grieving will receive a grant of 9,000,000 (2021). This is decided in the RAT. For example, if the husband dies, the husband who is a member will receive 9,000,000 in funds. Then if the wife is also a member, the grieving 
wife will also receive a grant of 4,000,000

The total amount of aid provided is $13,000,000$

(the exact amount is not yet known). This activity is based on the principle that cooperatives always try to help alleviate the difficulties of other cooperative members. The point is that we are middle to lower-class people, but we want to help our friends, even if it's a little."

Table 2. Realization of the Swastiastu Credit Cooperative Social Fund in 2020

\begin{tabular}{|c|l|r|r|}
\hline No. & \multicolumn{1}{|c|}{ Type of Social Fund } & Amount & IDR \\
\hline 1 & Member education fund assistance & 300 & 221.850 .000 \\
\hline 2 & $\begin{array}{l}\text { Education fund assistance for the insured } \\
\text { members }\end{array}$ & 206 & 72.950 .000 \\
\hline 3 & Hospitalization members & 241 & 103.000000 \\
\hline 4 & Insured member hospitalization & 25 & 72.300 .000 \\
\hline 5 & Assistance for outstanding students & 26 & 7.800 .000 \\
\hline 6 & $\begin{array}{l}\text { Social donations (Traditional Villages, } \\
\text { Ceremonies, etc.) }\end{array}$ & 1.536 & 400.000 \\
\hline & & & 491.600 .000 \\
\hline
\end{tabular}

Source: 2020 Management Accountability Report

Table 3. Realization of the Swastiastu Credit Cooperative Social Fund in 2020

\begin{tabular}{|c|l|c|c|}
\hline No. & \multicolumn{1}{|c|}{ Type of Social Fund } & Amount & IDR \\
\hline 1 & $\begin{array}{l}\text { Compensation for mourning members } \\
\text { January-February }\end{array}$ & 10 & 30.000 .000 \\
\hline 2 & Insured member's Educational Fund Assistance & 44 & 132.000000 \\
\hline 3 & Hospitalization members & 44 & 608.000 .000 \\
\hline & & 1.536 & \\
\hline
\end{tabular}

Source: 2020 Management Accountability Report

The policy of social funds and funeral funds is a social aspect based on the belief that every member of the cooperative must help other cooperative members who are experiencing difficulties, even in small amounts per person. The current value of 2,000 rupiah is undoubtedly not burdensome, but the benefits are enormous for assisted members when facing difficulties in this case due to death.

\section{CONCLUSION}

Based on the results of the research and discussion described previously, the conclusions that can be drawn from this research are: (1) Management of residual business results at the Swastiastu Credit Cooperative is allocated to several elements, namely reserve funds, depositor services, borrowing services, management funds, employee funds, social funds, DPDK funds, and education funds, (2) Social accounting at the Swastiastu Credit Cooperative is shown by the existence of a social fund program and a funeral fund with the premise of helping each other among members of the cooperative as well as to contribute to community activities around the cooperative. Suggestions conveyed in this study are to add more in-depth interviews with key informants and explore more information about social accounting in cooperatives.

\section{AUTHORS' CONTRIBUTIONS}

The three of us contributed to this article. Lucy Sri Musmini as coordinates research and article writing activities. Luh Indrayani helped with the preparation and data collection. I Gede Agus Pertama Yudantara the research data analysis.

\section{ACKNOWLEDGMENTS}

We are grateful to Universitas Pendidikan Ganesha especially the LPPM Undiksha and the Faculty of Economics for your support so this article can be realized. 


\section{REFERENCES}

[1] J. Elkington, The Triple Bottom Line of 21st Century Business. United Kingdom: Capstone Publishing Limited, 1997.

[2] E. G. Sukoharsono, Laba Akuntansi dalam Multiparadigma, Pertama. Malang: Tunas Unggul, 2009.

[3] N. F. Jahan, "Social Accounting \& Social Responsibility Reporting: An Overview," Vishwakarma Bus. Rev., no. July, pp. 1-9, 2010.

[4] C. Spence, "Accounting for the dissolution of a nation state : Scotland and the Treaty of Union," Accounting, Organ. Soc., vol. 35, no. 3, pp. 377392, 2010, doi: 10.1016/j.aos.2009.09.005.

[5] S. Killian and P. O. Regan, "Accounting, Organizations and Society Social accounting and the co-creation of corporate legitimacy," Accounting, Organ. Soc., vol. 50, pp. 1-12, 2016, doi: 10.1016/j.aos.2016.02.004.

[6] 1992 UU No. 25, "UU Republik Indonesia Nomor 25 Tahun 1992 Tentang Perkoperasian," 1992.

[7] 2015 Permen KUKM No.13, "Peraturan Menteri Koperasi dan Usaha Kecil dan Menengah Republik Indonesia Nomor 13 Tahun 2015 Tentang Pedoman Akuntansi Usaha Simpan Pinjam oleh Koperasi,” 2015.

[8] U. Ludigdo, "Gagasan untuk Pembentukan Undang-Undang Perkoperasian. Makalah Seminar Nasional dalam Rangka Uji Empirik Perumusan Materi Ruu Koperasi dengan Tema Telaah Filisofis, Yuridis, dan Strategis Empirik.," 2015.

[9] A. Abbas, Bung Hatta dan Ekonomi Islam: Menangkap Makna Maqashid al Syari'ah. Jakarta: Penerbit Buku Kompas, 2010.

[10] S. E. Swasono, Kebersamaan dan Asas Kekeluargaan: Kerakyatan, Nasionalisme, dan Kemandirian. Jakarta: Penerbit Universitas Pendidikan Jakarta, 2005.

[11] H. Suryokumoro, "Undang-Undang Berdasarkan Jati Diri Koperasi. Makalah Seminar Nasional dalam Rangka Uji Empirik Perumusan Materi RUU Koperasi dengan Tema: Telaah Filosofis, Yuridis, dan Strategis Empirik.," 2015, pp. 1-9.

[12] S. E. Swasono, "Koperasi Sebagai Mata Kuliah di Universitas: Dapatkah Koperasi Menjadi Pilar Orde Ekonomi Indonesia? Makalah Seminar Bulanan Ke -5 PUSTEP-UGM .," 2003, p. 2003.

[13] M. Hatta, Membangun Koperasi dan Koperasi Membangun, Gagasan dan Pemikiran Hatta. Jakarta: Penerbit Buku Kompas, 2015.
[14] D. Suputra, Refleksi nilai-nilai akuntansi dalam organisasi subak di bali. Malang, 2011.

[15] J. W. Creswell, Qualitative Inquiry and Research Design Choosing Among Five Approaches, Third Edit. California: Sage Publications, 2013.

[16] G. Burrell and G. Morgan, Sociological Paradigms and Organisational Analysis. Burlington, 1979.

[17] E. G. Sukoharsono and N. A. Putra, "Creating Shared Value ( CSV ) Rural Development Sector at PT Nestle Kejayan Factory: An Ethnographical Study of Jabung Agro Niaga Cooperative and Pujon SAE Cooperative as a Reference Development of Corporate Social Responsibility ( CSR ) Based on Social," in Conference on Accounting and Business, 2013, no. August, pp. 1-21.

[18] J. L. Retolaza and L. San-Jose, "Understanding Social Accounting Based on Evidence," SAGE Open, vol. 11, no. 2, 2021, doi: $10.1177 / 21582440211003865$ 